\title{
Scientific freedom: new strategies are needed
}

\author{
Threats to the flow of knowledge may come from small groups as well as governments.
}

Sir - The International Council for Science (ICSU) welcomes your timely publication of the Commentary by Blakemore et al., "Is a scientific boycott ever justified?" (Nature 421, 314; 2003). We are pleased that the authors draw a conclusion directly aligned with ICSU's 'universality of science' principle (see www.icsu.org/Library/Central/Statem/ freecondsc.html) — that the unrestricted flow of scientific ideas and information is critical to the advancement of science in stating that there would be few, if any, circumstances in which the principle should be overridden.

Since its inception in 1931, ICSU has affirmed the fundamental rights of scientists to pursue research and publish results, to associate freely, and to share materials. We have publicly upheld this principle through the political and social turmoil of the Second World War, the Cold War and apartheid. Our work to protect the rights of individual scientists - often undertaken out of the limelight — has been steady and successful.

As Blakemore et al. suggest, each situation is unique and calls for a considered response, not just from ICSU, but also from its members (the 101 national members and 27 scientific unions for which adherence to the principle is a condition of membership) and from the entire scientific community.

The Commentary was prompted by a call - made by Blakemore, his coauthor Richard Dawkins and 123 other academics, in a letter to Britain's Guardian newspaper on 6 April 2002 - for national and European agencies to suspend Israel's eligibility for academic funding until Israel agreed to abide by UN resolutions and open serious peace negotiations with the Palestinians. Others subsequently called for boycotts of Israeli scientists, and two journals decided to exclude Israeli scholars from their editorial boards. (See also Correspondence by M. Fainzilber, Nature 417, 15; 2002; and by S. Rose \& H. Rose, A. Abbes et al., and M. Mangel, Nature 417, 221-222; 2002.)

These events prompted ICSU to issue a public statement denouncing the proposed boycotts to our membership and the media in September 2002 (see www.icsu.org/ Media/press/pdf_releases/release1.htm).

Recognizing that the Israeli boycott issue is only one example of the current threats to the universality principle, ICSU is reviewing the principle in the context of the twenty-first century. We are closely monitoring additional calls for boycotts of Israeli scholars in the French scientific community, as well as security measures that effectively limit the publication of scientific data. We have actively voiced our concern regarding visa regulations that restrict the travel of scientists from specific countries and/or disciplines.

Blakemore et al. have highlighted apparent definitional ambiguities in the principle as currently worded, identifying ethical dilemmas (individual and institutional) that warrant consideration. In today's environment, threats to the principle are as likely to arise from the activities of individuals or small groups as from the policies of a particular government. Clearly, ICSU needs to develop strategies to address these new circumstances. As we undertake this important task, we welcome input from the broad scientific community. In advance of its meeting, scheduled for March, ICSU's Standing Committee on Freedom in the Conduct of Science (SCFCS) invites readers to forward additional questions and comments to its chair, Peter Warren, at peter.warren @beech5.demon.co.uk.

Jane Lubchenco (president), Thomas Rosswall (executive director), Peter Warren and all members of the executive board and SCFCS

International Council for Science, 51 boulevard de Montmorency, 75016 Paris, France

\section{Scientific freedom: some face a lonely dilemma}

Sir - The Commentary (Nature 421, 314; 2003) by Blakemore et al., on the principle of the universality of science and its obligations on scientists, prompts me to suggest that we should be engaging in a more urgent debate on the role of scientists in legally constituted weapons inspections. The urgency relates to Iraq and the appalling and lonely dilemma that some Iraqi scientists may be facing.

Scientists, like other citizens, have to obey the law of the land, their conscience and the ethical demands of their profession. Many also frame these as religious obligations. Additionally, in the context of disarmament, they have to consider whether they are bound by international laws to which their state either has, or has not, subscribed. They will have loyalties to their country, and may be bound by official-secrets laws. If scientists find any of these demands in conflict, they will encounter naked power and the raw sentiment of fellowcountrymen intolerant of disloyalty.

The approach taken by Blakemore et al., of testing precepts through case histories, is instructive. We could take the case of a Czech defence scientist in 1938. Suppose the scientist knew that the country had not fully dismantled defensive structures as 'agreed' in the Munich Treaty. Or what if an individual is engaged in the development of weapons that the country has legally undertaken not to acquire? And if a scientist is ordered to hide from inspectors documents that have international legitimacy, but whose authority runs counter to national obligations, what action should he or she take?

One option is that of whistle-blowing on the country's failure to comply with its legal obligations. But should an individual's opinion on the motives of either regime inform this judgement? If the individual considers the position of both sides to be morally indefensible, would this change the obligation to divulge? Can such a lack of clean hands be allowed to shade one's willingness to risk liberty and life? And would incompetent concealment be an acceptable moral position or an irresponsible fudge?

Roger Macy

28 Dorking Road, Tunbridge Wells, Kent TN1 2LP, UK

\section{Gene flow might turn wimps into superweeds}

Sir - Your News story "Transgenic crop trial's gene flow turns weeds into wimps" (Nature 421, 462; 2003) highlights the suggestion that gene flow between transgenic crops and potential weeds can act to lessen the latter's negative effects on important crop plants.

The researchers, Neal Stewart and colleagues, seem to reach this conclusion on the basis of short-term results consisting of a decreased negative effect of initial hybrid weeds on wheat yield when compared to the effects of non-hybrid weeds. Stewart et al. apparently attribute this to the reduction of fitness of otherwise well-adapted weeds through the inheritance of genes with high genetic load (that is, deleterious mutations) from the transgenic crop plant. 
But the observation that initial hybrids are less aggressive and apparently unable to benefit immediately from such inheritance is not of much importance to agriculturalists. What is important is the evolutionary potential for transgenic crop genes to be shifted and shuffled around in a way that may eventually result in a novel modified gene complex.

Just as Clark Kent was able to change into Superman - as your News story put it - such a novel complex, initially born an inferior weakling, may very well have a chance of becoming a 'superweed'.

Norris Muth

Department of Ecology and Evolutionary Biology,

University of Tennessee, Knoxville, Tennessee

37996-1610, USA

\section{Venezuelan government is backing science}

Sir-Mendoza et al. in Correspondence (Nature 421, 473; 2003) ask for help in the name of the Venezuelan scientific community, in view of the current turmoil in our country. However, as we show here, the real figures tell a different story, pointing to the efforts made by the current government, which has been in power since 1999, to satisfy the demands of the scientific sector.

More than $60 \%$ of Venezuela's science budget comes from the government. During the past ten years, total investment has continuously increased, from US $\$ 177$ million in 1990 to $\$ 405$ million during 2000. In 2001, the state science budget was, astonishingly, increased by more than 50\%, reaching $\$ 637$ million. As a consequence there have been more grants for established researchers, as well as a significant improvement in economic support for graduate students.

Notably, Venezuela spends more on science and technology activities per researcher than any other country in North or South America apart from the North American Free Trade Agreement (NAFTA) countries: Canada, Mexico and the United States. In 1999, while the NAFTA countries spent $\$ 126,000$ per researcher, Venezuela spent $\$ 76,000$, compared with an average expenditure of just $\$ 62,000$ per researcher in the countries of Latin America and the Caribbean region. In 2000 Venezuela's spending increased to $\$ 86,000$ per researcher, while the average in Latin America and the Caribbean went down to $\$ 61,000$ (see www.ricyt.edu.ar).

The current government has created a Ministry of Science and Technology and approved the first law promoting science and technology in our country's history.
Regional governments are now required to contribute part of their budgets to science, and a considerable amount of money has been devoted to regional programmes. We believe that the present government has provided benefits to the scientific community, and that its significant efforts for the advancement of science in Venezuela should be recognized.

A considerable number of enthusiastic science students and other young scientists in Venezuela have shown their dedication to science during the current social and political conflict, in particular during December and January, when many of them kept working despite transport difficulties caused by petrol shortages and illegal road blocks.

Despite the efforts made by some political and economic sectors to destabilize the democratically elected government, many members of the scientific community are confident that Venezuelan science will overcome this adverse situation in the near future.

Undoubtedly, though, the current crisis will have a negative effect on this year's science budget (see "Venezuelan science hit by national strikes", www. scidev.net, 7 February 2003).

Juan Luis Cabrera ${ }^{\star}$, Luis Emilio Guerrero $\dagger$, Arnaldo Donoso*

${ }^{*}$ Centro de Física, Instituto Venezolano de Investigaciones Científicas, Apartado 21827, Caracas 1020-A, Venezuela

$\dagger$ Departamento de Física, Universidad

Simón Bolivar, Apartado 89000,

Caracas 1080-A, Venezuela

Other signatories to this letter can be found at

http://caos.fs. usb.ve/carta.html

\section{Free access to publicly funded databases is vital}

Sir - The International Society for Computational Biology (www.iscb.org) wishes to express regret and concern about the decision by the US Department of Energy (DOE) to shut down the PubScience web site (see Nature 411, 980; 2001 and 418, 805; 2002). Unfortunately this decision came to our attention too late to comment before the DOE's official deadline passed.

Free access to scientific knowledge and data is essential to scientific progress. Free access to publicly funded databases such as PubScience, PubMed, Medline and GenBank reflects the public's role in funding the science that led to these data, and provides a cost-effective means for disseminating information to the scientific community. It is essential to future progress in scientific research that these public information resources remain freely accessible. Philip E. Bourne

President, International Society for Computational Biology, San Diego Supercomputer Center, University of California, San Diego, 9500 Gilman Drive, La Jolla, California 92093-0505, USA

\section{GreenSea's interest in fertilizing sea with iron}

Sir-Your News feature "The oresmen" (Nature 421, 109-110; 2003) characterizes the objectives of GreenSea Venture as strongly in favour of episodic iron fertilization of selected high-nutrientlow-chlorophyll ocean areas, a nonpolluting and inexpensive technique. In fact, we believe only that this may be an efficacious approach to controlling the concentration of carbon dioxide in the atmosphere.

Our activities are in support of 'sound science' and the further development of knowledge applicable to iron fertilization as a carbon-control technology. Only with such knowledge can policy-makers determine whether this technology should be developed, together with other approaches, for efforts at climate control. M. Lee Rice

GreenSea Venture, Inc., 20150 Woodtrail Road, Round Hill, Virginia 20141-1943, USA

\section{Eastern Europe nurtures talent for the West}

Sir - As a scientist from Slovakia, one of the Eastern European countries in the process of joining the European Union, I was pleased to see your Opinion article "Too quiet on the Eastern front" discussing science in Eastern Europe (Nature 421, 459; 2003).

After spending five years doing my $\mathrm{PhD}$ in Austria and two more years as a postdoc in England, I was interested in returning to Slovakia to pursue my scientific career there. I was kindly offered a university position with the possibility of starting my own group - but the salary was only SKK100,000-200,000 $(\$ 2,550-\$ 5,100)$ a year. Because I have two children I had no choice but to look for other options.

I have realised that, unfortunately, there are no fellowships that would allow me to go back to Slovakia. The situation is similar in all Eastern European countries: universities nurture talents for the Western countries.

Juraj Gregan

Department of Zoology, University of Oxford, South Parks Road, Oxford OX1 3PS, UK 